\title{
EVALUASI PENGARUH LINGKUNGAN AKIBAT BENCANA GEMPA DI KAWASAN WISATA GUNUNG KIDUL
}

\author{
Indah Yuliasari \\ Universitas Indraprasta PGRI, Jakarta \\ yuliasari.wibowo@gmail.com
}

\begin{abstract}
Earthquake Disasters affect the order of people's lives and the property of the people is destroyed and economic production also decreases. This implies that people living in the affected areas experience job losses. On the other hand, damage to areas due to disasters has become a tourist attraction that can create new employment opportunities. This study aims to analyze the environmental impact of the earthquake disaster on changes in community work in the study area. Regional potential can balance the hazards contained within the region so that the community decides not to move from the affected area even though the area is dangerous. The method used is semi-ethnographic qualitative analysis with purposive sampling sampling technique. The method of data analysis itself is carried out with qualitative analysis, where this analysis is beneficial because truth can only be obtained from the field. There are three sequential analyzes, namely data reduction, data presentation, and conclusion drawing. What makes the tourism sector appear is the direct impact of disasters in the form of environmental damage and social capital. The issue of severe environmental damage raises the curiosity of tourists to visit and witness the impact of the disaster in Gunung Kidul district directly. In assessing the impact on a sector is comparing assets that existed before a disaster and after a disaster. If this livelihood activity can survive despite all the pressures and threats, then the activity can be said to be a sustainable livelihood. From this study it can be concluded that disasters have an impact on changes in community work because people who lose their jobs are able to take advantage of employment opportunities elsewhere as new livelihoods. The main thing is the existence of government support to create sustainable work for the community.
\end{abstract}

Key Words: disaster, impact, earthquake

\begin{abstract}
Abstrak : Bencana Gempa mempengaruhi tatanan kehidupan masyarakat dan harta benda masyarakat hancur dan produksi ekonomi pun menurun. Hal ini mengisyaratkan bahwa masyarakat yang tinggal di daerah bencana mengalami kehilangan pekerjaan. Di sisi lain, kerusakan wilayah akibat bencana justru menjadi daya tarik wisata yang dapat memunculkan peluang kerja baru. Penelitian ini bertujuan untuk menganalisis dampak lingkungan akibat bencana gempa terhadap perubahan pekerjaan masyarakat di wilayah studi. Potensi wilayah dapat menyeimbangkan bahaya yang terdapat di dalam wilayah tersebut sehingga masyarakat berkeputusan untuk tidak pindah dari daerah bencana meski daerah tersebut berbahaya .Metode yang digunakan adalah analisis kualitatif semi-etnografi dengan teknik pengambilan sampel purposive sampling. Metode analisis data sendiri dilakukan dengan analisis kualitatif, di mana analisis ini menguntungkan karena kebenaran hanya bisa didapatkan dari lapangan. Terdapat tiga analisis yang berurutan, yakni reduksi data, penyajian data, dan penarikan kesimpulan. Hal yang membuat sektor pariwisata muncul adalah dampak langsung bencana berupa kerusakan lingkungan serta modal sosial. Isu mengenai kerusakan lingkungan yang parah memunculkan rasa penasaran wisatawan untuk berkunjung dan menyaksikan dampak bencana di kabupaten Gunung Kidul secara langsung. Dalam menilai dampak terhadap suatu sektor adalah membandingkan aset yang ada sebelum bencana dan setelah bencana. Jika kegiatan penghidupan ini dapat bertahan meski menghadapi segala tekanan dan ancaman, maka kegiatan tersebut dapat dikatakan sebagai penghidupan yang berkelanjutan Dari penelitian ini dapat disimpulkan bahwa bencana berdampak pada perubahan pekerjaan masyarakat karena masyarakat yang kehilangan pekerjaan mampu memanfaatkan peluang kerja di tempat lain sebagai sumber penghidupan baru. Hal paling utama adalah keberadaan dukungan pemerintah untuk menciptakan pekerjaan berkelanjutan bagi masyarakat.
\end{abstract}

Kata Kunci : bencana,gempa, pengaruh, wisata 


\section{PENDAHULUAN}

Bencana alam dapat memberikan dampak kelesuan ekonomi lokal serta hilangnya mata pencaharian penduduknya. Pengaruh dari semua itu adalah terganggunya kondisi sosial serta ekonomi wilayah yang mengalami bencana. Menurunnya aktifitas suatu wilayah tersebut juga diperparah oleh hancurnya sarana pendukung kegiatan ekonomi seperti permukiman penduduk, saluran telekomunikasi, pembangkit energi, dan sarana transportasi .

Sebelum terjadi bencana, masyarakat yang tinggal di kawasan Gunung Kidul hidup dengan berbagai macam aktivitas. Sebagian besar masyarakat bekerja sebagai petani dan peternak. Akibat gempa, produksi komoditas unggulan pertanian dan ternak menurun sehingga banyak petani kehilangan pekerjaan. Di sisi lain, kerusakan wilayah yang ditimbulkan oleh bencana justru menimbulkan rasa penasaran wisatawan untuk berkunjung ke bekas daerah bencana. Jika dikelompokkan dalam jenis pariwisata, kegiatan wisata ini dapat masuk ke dalam jenis pariwisata gelap (dark tourism). Dark tourism mengacu pada produk dan tempat yang dapat menarik pengunjung yang berminat pada bencana.

Melihat adanya peluang untuk mengubah bencana menjadi berkah, maka kawasan bencana pun dibuka menjadi kawasan wisata . Kawasan wisata dapat membuka peluang pekerjaan bagi masyarakat secara langsung maupun tidak langsung. Dengan demikian, diperkirakan sebagian besar masyarakat lokal yang semula bekerja di bidang pertanian dan peternakan kini berganti pekerjaan menjadi pekerja di kawasan wisata sebagai salah satu strategi untuk bertahan hidup. Penelitian ini bertujuan untuk menganalisis dampak gempa terhadap perubahan pekerjaan masyarakat sehingga kini mereka memiliki pekerjaan di Kawasan Wisata Gunung Kidul. Untuk mencapai tujuan tersebut, terdapat beberapa sasaran dalam penelitian ini, antara lain:

1. Menganalisis dampak dari bencana terhadap hilangnya pekerjaan masyarakat pada wilayah studi.

2. Menganalisis peran kawasan wisata Gunung Kidul sebagai peluang kerja dan sumber pendapatan baru bagi masyarakat.

3. Menganalisis alasan masyarakat melakukan perubahan pekerjaan.

Fokus dari penelitian ini adalah dampak tidak langsung bencana, khususnya pada lingkungan dan masyarakat. Pengetahuan serta pemahaman mengenai dampak, baik langsung maupun tidak langsung merupakan hal yang penting untuk dilakukan dalam rangka mewujudkan pemulihan bencana yang berkelanjutan, akan tetapi pemahaman pengaruh tidak langsung kurang maksimal dilakukan saat penanggulangan bencana. Pemerintah seringkali hanya terfokus pada pemulihan secara langsung seperti kerusakan fisik wilayah tanpa memperhatikan pengaruh secara tidak langsung khususnya penurunan kemampuan masyarakat untuk kembali ke pekerjaan semula. Padahal penilaian terhadap dampak langsung dapat memberikan gambaran pada tahapan proses pemulihan yang harus berkaitan dengan pemulihan fisik. Dengan adanya pemulihan fisik dengan pemulihan sosial ekonomi, masyarakat akan mampu untuk memiliki kemampuan bertahan cukup tinggi. Melalui keberlanjutan ini maka masyarakat akan mampu mengurangi pengaruh yang ditimbulkan dan beradaptasi pada bencana yang mungkin bisa terjadi di masa mendatang.

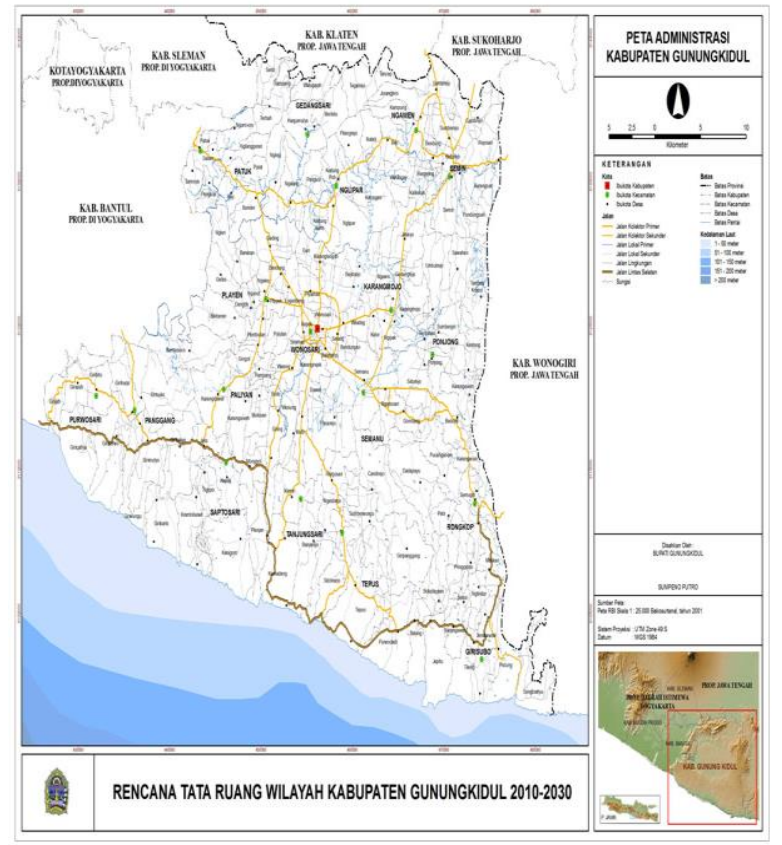

Gambar 1.Peta Administrasi kab Gunungkidul. Sumber: BAPPEDA GunungKidul

\section{Tinjauan Literature}

1. Dampak Bencana Gempa

Tidak semua peristiwa alam dapat digolongkan sebagai bencana. Bencana terjadi apabila suatu peristiwa ekstrem mengakibatkan korban harta benda dan bahkan korban jiwa. Dengan kata lain, selama peristiwa alam tidak menimbulkan korban, maka hal itu belum dapat dikatakan sebagai bencana alam. Dengan demikian, dampak terjadi apabila suatu komunitas mengalami ketidakmampuan dalam 
mengatasi peristiwa alam yang ekstrem. Terdapat dua jenis dampak bencana, yaitu dampak langsung dan tidak langsung. Dampak langsung terjadi ketika peristiwa bahaya sedang berlangsung. Sementara dampak tidak langsung dirasakan setelah peristiwa bahaya telah berlalu, dampak tidak langsung terjadi akibat dampak langsung sehingga aliran barang dan jasa tidak berjalan seperti seharusnya. Kedua jenis dampak tersebut dibagi lagi menjadi terukur dan tidak langsung. Dampak terukur adalah dampak yang menyebabkan kerusakan pada barang dan jasa yang memiliki nilai, dengan demikian dampak terukur merupakan dampak yang dapat diukur. Dampak tidak terukur adalah dampak yang menyebabkan kerusakan pada barang dan jasa yang tidak memiliki nilai sehingga nilai dari kerusakan tersebut tidak dapat dihitung. Hal yang perlu diperhatikan dalam menilai dampak terhadap suatu sektor adalah membandingkan aset yang ada sebelum dan setelah bencana .

Berikut adalah dampak-dampak yang ditimbulkan dari bencana gempa.

1. Dampak Langsung, dampak yang terjadi pada saat peristiwa bencana terjadi.

a. Dampak Langsung Terukur, yakni dampak yang terjadi pada saat peristiwa bencana baru saja terjadi dan besaran dampak tersebut dapat diukur. Dampak langsung terukur yang paling umum terjadi adalah kerusakan fisik suatu wilayah.

b. Dampak Langsung Tidak Terukur, yakni dampak yang terjadi ketika peristiwa bahaya baru saja terjadi dan akan tetapi besaran dampak ini tidak dapat terukur.

2. Dampak Tidak Langsung, dampak yang terjadi dalam jangka waktu tertentu setelah peristiwa bencana terjadi .

a. Dampak Tidak Langsung Terukur, merupakan dampak yang terjadi ketika peristiwa bahaya baru saja terjadi, akan tetapi besaran dampak ini dapat terukur. Contoh-contoh dampak tindak langsung terukur antara lain penurunan produksi pertanian, peternakan, industri, serta bidang ekonomi lainnya.

b. Dampak Tidak Langsung Tidak Terukur merupakan dampak yang terjadi dalam jangka waktu tertentu setelah peristiwa bahaya dan besaran dampak ini tidak dapat terukur. Misal penyakit dan dampak psikososial.
2. Manajemen Bencana

Manajemen bencana adalah seluruh kegiatan, program, dan langkah-langkah yang dapat diambil sebelum, selama, dan setelah bencana dengan tujuan untuk menghindari bencana, mengurangi dampak, dan memulihkan wilayah beserta penduduk yang tinggal di dalamnya dari kerugian . Manajemen bencana yang baik adalah manajemen bencana yang terintegrasi. Pemahaman mengenai dampak akan memberikan pemahaman mengenai tindakan rehabilitasi dan rekonstruksi. Ada pun definisi dari rehabilitasi dan rekonstruksi antara lain:

1. Rehabilitasi

Rehabilitasi adalah aktivitas untuk mengembalikan pelayanan dasar dan infrastruktur ke standar operasi minimum.

2. Rekonstruksi

Rekonstruksi adalah pembangunan kembali semua prasarana dan sarana, kelembagaan pada wilayah pascabencana, baik pada tingkat pemerintahan maupun masyarakat dengan sasaran utama tumbuh dan berkembangnya kegiatan dan bangkitnya peran serta kehidupan bermasyarakat pada wilayah pascabencana.

\section{Pariwisata dan Bencana Gempa}

Jika dikelompokkan dalam jenis pariwisata yang dilakukan di daerah bencana dapat masuk ke dalam jenis pariwisata gelap (dark tourism). Dark tourism mengacu pada produk dan tempat yang dapat menarik pengunjung yang berminat pada bencana. Kekuatan daya tarik dalam pariwisata gelap, tergantung pada seberapa besar peristiwa dan waktu terjadinya peristiwa tersebut. Semakin dekat dengan waktu kejadian, maka sifat dari pariwisata tersebut semakin gelap sehingga semakin memiliki daya tarik. Sifat semakin gelap dari suatu pariwisata juga dipengaruhi oleh besarnya peristiwa. Semakin besar peristiwa yang terjadi, semakin banyak korban, dan semakin besar dampak yang ada maka semakin kuat daya tarik yang ada di tempat pariwisata tersebut.

Pariwisata gelap juga seringkali dilakukan di daerah pegunugan berapi. Kategori wisatawan ada empat tipe, yaitu wisatawan massal yang terorganisasi, wisatawan massal individual, eksplorer, dan drifter. Orang-orang yang melakukan wisata bencana gempa dikelompokkan ke dalam kelompok eksplorer. Eksplorer merupakan tipe wisatawan yang 
menghindari untuk melakukan wisata pada rute yang umum atau sering dilewati oleh sebagian besar wisatawan lain. Wisatawan jenis ini suka untuk mengeksplor jalan baru untuk menuju ke tujuan dan tidak pernah mengharapkan kemewahan dan kenyamanan. Tujuan mereka berwisata adalah untuk melakukan aktualisasi diri dan belajar tentang kebudayaan lokal dengan ide baru dan pikiran yang terbuka. Hal ini karena poin yang dijual pada pariwisata tersebut merupakan sesuatu yang unik, yakni campuran antara rasa ingin menantang diri sendiri dengan sesuatu berbahaya yang dikombinasikan dengan rasa penasaran terhadap ilmu pengetahuan dan pendidikan. Dengan demikian kegiatan pariwisata tersebut merupakan kegiatan wisata yang sangat berpotensi untuk memberikan keuntungan.

\section{Pengaruh Mata Pencaharian Masyarakat.}

Bencana alam dapat memberikan dampak dalam menghilangkan mata pencaharian masyarakat. Selama masa krisis, masyarakat menjadi tergantung pada bantuan tapi tidak bisa berlangsung lama, terlebih apabila bantuan tersebut tidak dapat memenuhi seluruh kebutuhan dan mengembalikan kehidupan masyarakat normal kembali. Sehingga diperlukan usaha masyarakat yang dilakukan dengan cara memulihkan mata pencaharian. Perubahan yang terjadi karena musim pada umumnya lebih mampu diprediksi, akan tetapi hal yang datangnya tiba-tiba seperti tekanan seringkali menyerang rumah tangga perdesaan tanpa peringatan sama sekali sehingga membatasi kemampuan masyarakat untuk mempersiapkan diri dan mengurangi dampak yang akan dialami.

Strategi penghidupan lain yang diterapkan untuk mengatasi bencana adalah hidup berdamai dengan bencana. Beberapa masyarakat memilih untuk tetap tinggal di kawasan bencana karena potensi yang dimiliki oleh kawasan tersebut dapat memberikan penghidupan. Potensi wilayah dapat menyeimbangkan bahaya yang terdapat di dalam wilayah tersebut sehingga masyarakat berkeputusan untuk tidak pindah dari daerah bencana meskipun daerah tersebut berbahaya. Ada tindakan yang dapat dilakukan oleh masyarakat untuk hidup dengan risiko bencana, antara lain:

1.Tidak melakukan apapun

2.Melindungi masyarakat dari bahaya 3.Menghindari bencana

4.Hidup dengan bahaya dan risiko.

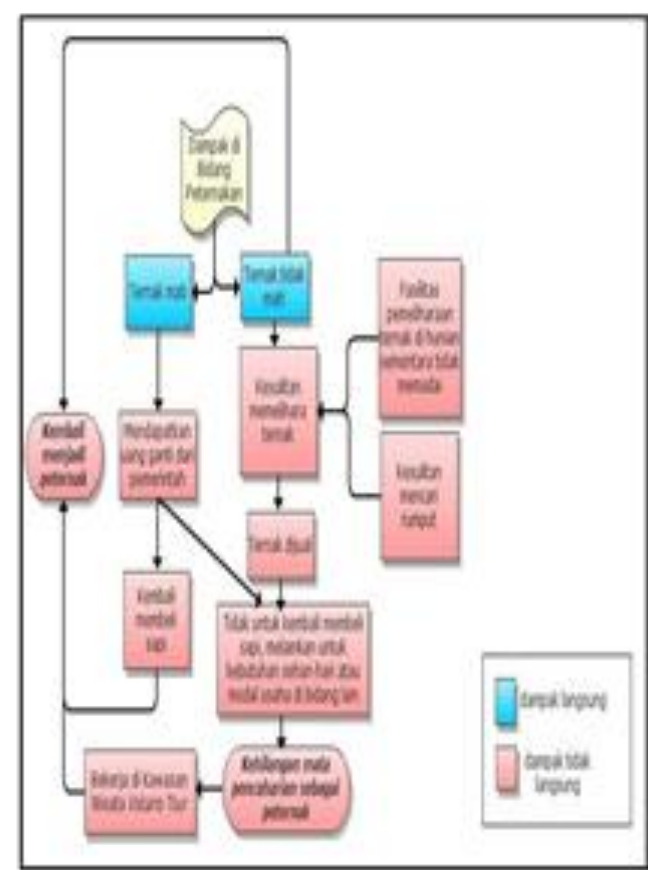

Gambar 2. Pengaruh Bencana terhadap Hilangnya Mata Pencaharian di desa Klampok, Parangendog, Watugupit, Purwosari.

Sumber: Hasil Analisis, 2016

\section{METODOLOGI}

Penelitian ini dilakukan dengan menggunakan pendekatan semi-etnografi. Tujuan dari riset semi-etnografi adalah untuk memformulasikan pola analisis untuk menghasilkan suatu kesimpulan yang masuk akal dari setiap perbuatan manusia dalam konteks waktu dan tempat yang spesifik. Penggunaan semietnografi dalam studi ini juga dimaksudkan agar peneliti memahami sudut pandang hidup dari sudut pandang penduduk asli.

Metode pengumpulan data dilakukan dengan pendekatan makro dan mikro. Pendekatan makro dilakukan di awal agar penulis dapat memahami permasalahan secara makro sebelum secara langsung melihat kasus di lapangan. Pendekatan ini menggunakan tiga sumber utama, yakni sumber ilmiah terkait, surat kabar dan media massa lainnya, serta laporan pemerintahan.

Sementara itu pendekatan mikro dilakukan dengan cara observasi wilayah studi dan wawancara. Ada pun informan dari golongan masyarakat yang diwawancarai antara lain pekerja di kawasan wisata, peternak, pengelola, sementara informan dari golongan pemerintah dan instansi lainnya adalah kepala desa, kepala bidang peternakan Dinas Pertanian, Perikanan, dan Kehutanan, staff bidang pemasaran Dinas Kebudayaan dan Pariwisata, Kepala bidang 
Perencanaan Perdesaan Badan Perencanaan Daerah Kabupaten Gunung kidul. Informan dari kalangan masyarakat diwawancarai untuk mendapatkan informasi mengenai dampak bencana. Sementara informan dari kalangan pemerintah diwawancara untuk mendapatkan informasi mengenai dampak bencana serta peran pemerintah dalam menanggulangi dampak bencana tersebut. Penentuan informan dilakukan dengan teknik snowball di mana informan sebelumnya merekomendasikan informan selanjutnya

Metode analisis data sendiri dilakukan dengan analisis kualitatif, di mana analisis ini menguntungkan karena kebenaran hanya bisa didapatkan dari lapangan. Terdapat tiga analisis yang berurutan, yakni reduksi data, penyajian data, dan penarikan kesimpulan.

Sebelum bencana, sebagian besar masyarakat bekerja sebagai peternak dan petani. Data dari Potensi Desa Klampok, Parangendog, Watugupit, Purwosari, menunjukkan bahwa pada tahun 2014, jumlah penduduk yang bekerja sebagai peternak dan petani adalah 2.600 orang atau sebesar $52 \%$ dari total penduduk desa, sedangkan pada tahun 2016, setelah terjadi bencana, masyarakat yang bekerja sebagai peternak dan petani hanya sebesar 300 orang atau sebesar $8 \%$ dari jumlah penduduk desa Klampok, Parangendog, Watugupit, Purwosari, secara keseluruhan. Artinya jumlah peternak dan petani berkurang sebesar 2300 orang jika dibandingkan pada tahun 2014. Penurunan jumlah peternak dan petani tersebut disebabkan oleh banyaknya ternak dan sawah yang menjadi korban bencana gempa, akan tetapi bukan hanya hal tersebut saja yang menjadi alasan. Hal lain yang juga menyebabkan masyarakat kehilangan pekerjaan adalah kondisi yang serba sulit dalam memelihara ternak di tempat penampungan. Penurunan jumlah peternak tersebut disebabkan oleh banyaknya ternak yang menjadi korban gempa pada tahun 2014, akan tetapi bukan hanya hal tersebut saja yang menjadi alasan. Pemerintah sebenarnya telah berusaha untuk memberikan uang ganti rugi misalnya pada ternak yang mati, yakni 10 juta untuk ternak induk, 6 juta untuk ternak dara, dan 4 juta untuk ternak yang masih kecil. Sebenarnya dengan uang tersebut bisa saja masyarakat kembali membeli ternak dan kembali menjadi peternak, akan tetapi karena dampak yang terjadi akibat bencana mencakup hampir seluruh aspek kehidupan, maka sebagian besar masyarakat lebih memilih menggunakan uang tersebut sebagai simpanan untuk pemenuhan kebutuhan seharihari.

\section{HASIL DAN PEMBAHASAN \\ Peran Kawasan Wisata Gunung Kidul sebagai Peluang Kerja Baru Bagi Masyarakat}

Selain karena adanya potensi wisata, faktor lain yang juga mempengaruhi pembukaan kawasan wisata ini adalah adanya kemampuan masyarakat Kecamatan Purwosari: Klampok, Parangendog, Watugupit, Purwosari untuk melihat potensi dan bergerak bersama dalam memanfaatkan potensi tersebut. Dengan demikian, atas inisiatif masyarakat maka kawasan ini dibuka sebagai kawasan wisata. Pembukaan Kawasan Wisata Gunung Kidul membuka peluang kerja sehingga masyarakat yang pada mulanya kehilangan pekerjaan sebagai peternak kini dapat memiliki aktivitas baru. Ada pun berbagai jenis mata pencaharian yang dilakukan oleh masyarakat di kawasan wisata Gunung Kidul antara lain petugas lapangan seperti petugas parkir dan tiket serta penyedia barang dan jasa seperti penjual makanan, penjual suvenir, dan penyedia jasa angkut. Segala kegiatan ekonomi yang berlangsung di kawasan wisata Gunung Kidul dikelola dan dikoordinir oleh seluruh masyarakat melalui wadah pengelolaan bernama Tim Pengelola yang diketuai oleh Kepala Desa Purwosari.

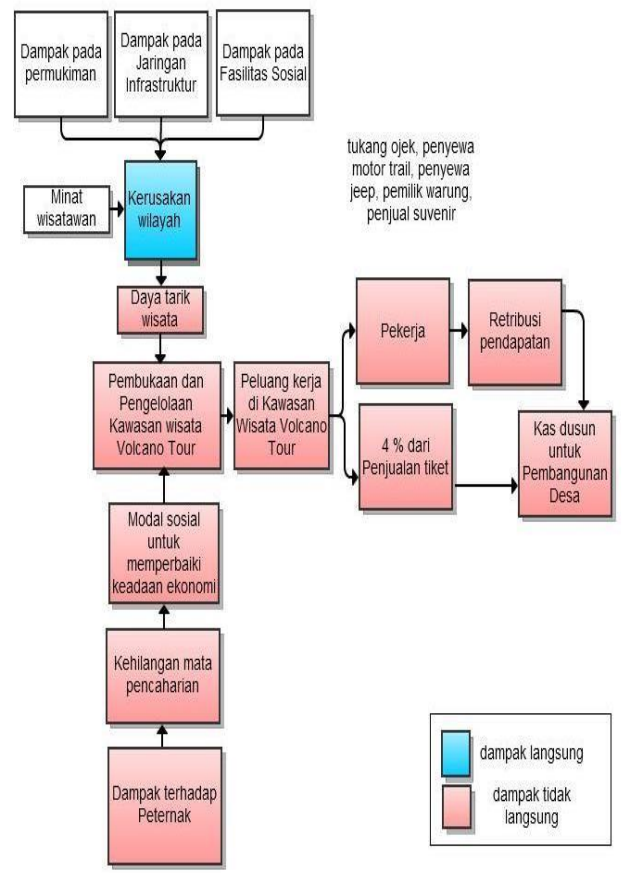

Gambar 3. Peran Kawasan Wisata Gunung Kidul 
Pemberian dana bantuan dari hasil penjualan tiket masuk dan parkir Kawasan Wisata Gunung Kidul diprioritaskan kepada masyarakatmasyarakat yang rentan, seperti lansia, anak yatim piatu, dan ekonomi lemah. Dana ini juga diprioritaskan kepada mereka yang mengalami kerusakan dan kerugian terparah.

\section{Alasan Perubahan Mata Pencaharian}

Pergantian sumber penghidupan ini ternyata terjadi pula pada masyarakat Kecamatan Purwosar, Klampok, Parangendog, Watugupit, Purwosari. Peristiwa gempa di Gunung Kidul pada tahun 2006 telah menyebabkan banyak kerusakan yang membuat masyarakat Kecamatan Purwosari: Klampok, Parangendog, Watugupit, Purwosari mengalami ketidakmampuan dalam mengatasi tekanan besar. Tekanan besar tersebut membuat aset penghidupan masyarakat menjadi hilang atau berkurang. Pada bencana gempa ini, aset penghidupan yang hilang serta berkurang adalah aset natural, fisik, dan finansial. Akibat dampak langsung tersebut, masyarakat tidak mampu kembali ke mata pencaharian sebelumnya, yaitu sebagai peternak sapi perah. Hal ini karena beberapa peternak mendapatkan ternaknya mati yang merupakan salah satu sumber daya penghidupan. Sehingga masyarakat berusaha mencari pendapatan dengan usaha memanfaatkan kesempatan kerja di sektor pariwisata. Sektor pariwisata ada karena pengaruh langsung bencana berupa kerusakan lingkungan. Informasi mengenai kerusakan lingkungan yang parah memunculkan rasa penasaran wisatawan untuk berkunjung dan menyaksikan dampak bencana di kawasan wisata Gunung Kidul.

Sirkulasi manusia untuk pergi ke daerah bencana untuk melihat langsung kerusakan, trauma, dan bencana disebut dengan dark tourism. Terbukanya peluang kerja baru di Kawasan Wisata Gunung Kidul juga didukung oleh adanya modal sosial masyarakat. Masyarakat dari Kecamatan Purwosari: Klampok, Parangendog, Watugupit, Purwosari menyadari bahwa dirinya mengalami keterpurukan ekonomi pascabencana dan mereka meyakini bahwa bekerjasama satu sama lain akan mempermudah pemulihan kondisi ekonomi.

Dengan demikian masyarakat secara bergotong royong membuka daerah bekas bencana sebagai kawasan wisata. Keberadaan modal sosial dalam memungkinkan masyarakat untuk mengambil peluang baru dalam bencana sehingga kemiskinan dan kerentanan yang dialami masyarakat dapat berkurang. Dengan demikian, dibukanya kawasan wisata Gunung Kidul memberikan kesempatan bagi masyarakat lokal untuk bekerja sebagai penjual suvenir, tukang ojek, penyedia jasa antar, pemilik warung, serta petugas lapangan. Sebagian besar masyarakat yang kehilangan pekerjaan sebagai peternak dan petani berganti mata pencaharian menjadi pekerja di sektor pariwisata. Masyarakat membentuk kelompok pengelola kawasan wisata yang membawahi beberapa paguyuban dan kelompok kerja. Paguyuban pekerja dan kelompok kerja memberlakukan sistim jadwal/waktu jaga dan retribusi pendapatan yang ketentuannya berbeda-beda tergantung pada jenis pekerjaan. Pemasukan hasil penjualan tiket dimasukkan ke dalam kas desa untuk pembangunan wilayah dan warganya. Keberadaan pengelolaan terpadu di Kawasan Wisata Gunung Kidul dapat menyalurkan manfaat dari kegiatan wisata dengan semakin banyak pengunjung berpotensi mengurangi kemiskinan akibat korban bencana.

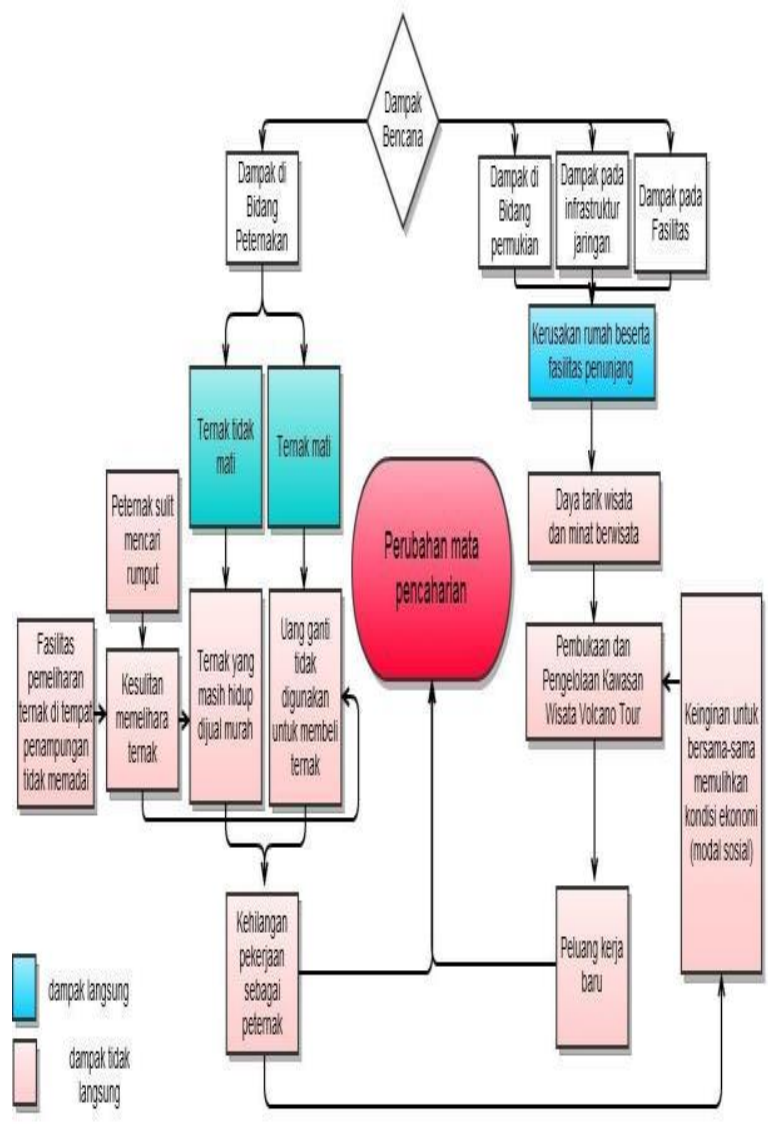

Gambar 4.. Faktor yang Mempengaruhi Perubahan Mata Pencarian Masyarakat Kecamatan Purwosari: Klampok, Parangendog, Watugupit, Purwosari Sumber: Hasil Analisis, 2016 


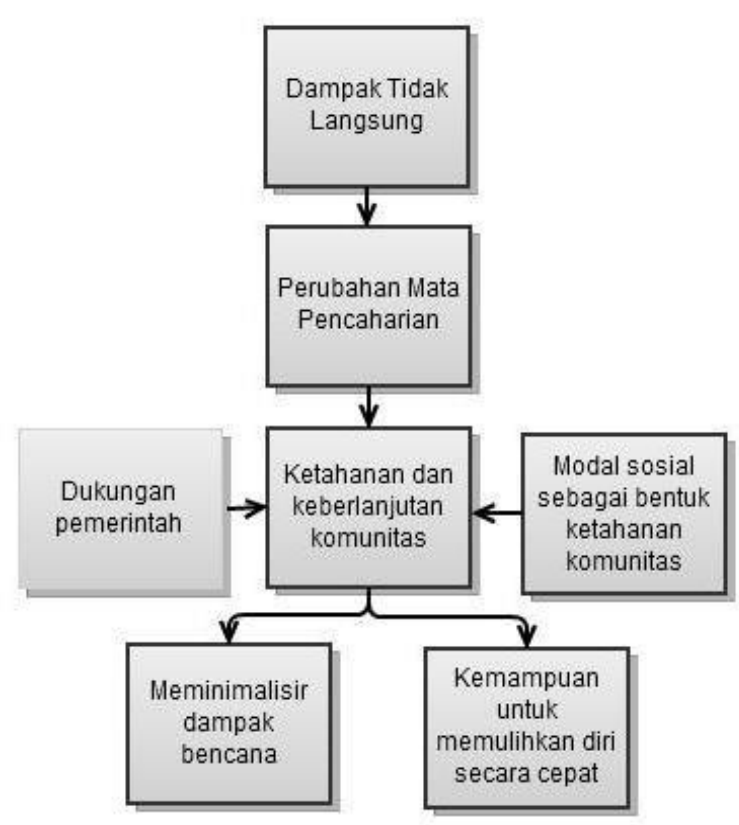

Gambar 5 Pengaruh Perubahan Mata Pencaharian

\section{Keberlanjutan Kawasan Wisata Gunung Kidul.}

Secara ekologis, kerusakan lingkungan berangsur-angsur mulai membaik, akan tetapi kegiatan wisata di Kawasan Gunung Kidul belum menunjukkan tanda-tanda dapat merusak lingkungan sehingga ia masih memiliki kesempatan untuk dilanjutkan keberadaannya. Akan tetapi kemampuan masyarakat lokal agar tetap mampu mengelola dan menjaga keberjalanan kegiatan wisata menjadi tantangan tersendiri untuk mewujudkan kegiatan penghidupan yang positif di Kawasan Wisata Gunung Kidul. Jika kegiatan penghidupan ini dapat bertahan meski menghadapi segala tekanan dan ancaman, maka kegiatan tersebut sebagai mata pencaharian yang mampu diharapkan. Semakin menurunnya daya tarik Kawasan Wisata Gunung Kidul, pemerintah tidak juga mengambil tindakan untuk mendukung pengembangan kegiatan wisata di kawasan ini. Ketiadaan dukungan optimal dari pemerintah ini juga mungkin menjadi salah satu faktor yang membuat daya tarik Kawasan Wisata Gunung Kidul tidak berkembang. Jika Kawasan Wisata Gunung Kidul ingin terus menjadi kawasan wisata yang menarik dan berkelas maka dukungan maksimal dari pemerintah sangat dibutuhkan.

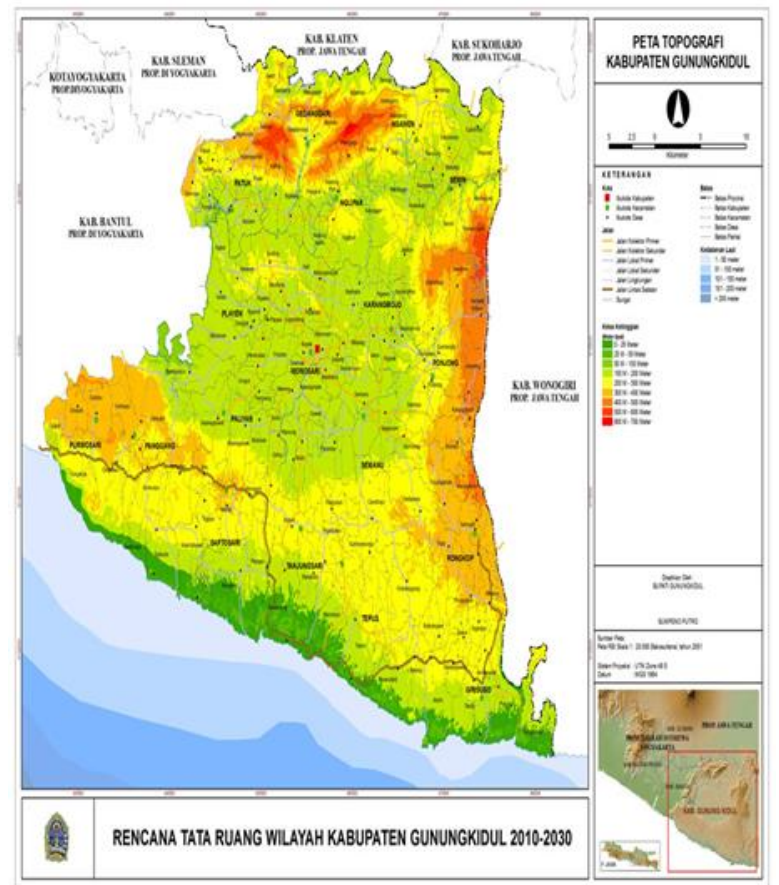

Gambar 6 Peta Topografi Kabupaten Gunung Kidul

Meski perencanaan dan perancangan pariwisata diperlukan, akan tetapi hal lain yang perlu diketahui adalah masyarakat kini sudah banyak yang kembali bekerja sebagai peternak dan petani. Mereka lebih memilih bekerja sebagai peternak dan petani dibandingkan pekerja di Kawasan wisata. Alasan yang mendasari pekerja untuk kembali menjadi peternak adalah pekerjaan sebagai peternak dinilai lebih menjanjikan karena memberikan penghasilan yang relatif tetap setiap bulannya, sedangkan pendapatan sebagai pekerja di sektor pariwisata cenderung tidak stabil dan tetap,karena besarannya tergantung dari jumlah wisatawan yang dating sehingga pekerjaan di Kawasan Wisata Gunung Kidul menunjukkan indikasi ketidakberlanjutan. Untuk membuat pekerjaan masyarakat di kawasan ini menjadi berkelanjutan, sebaiknya Dinas Kebudayaan dan Pariwisata Kabupaten Gunung kidul melakukan hal yang dapat mendukung kegiatan wisata, namun yang sifatnya tidak memicu pembangunan fisik di wilayah rawan bencana seperti peningkatkan kualitas SDM dan inovasi kegiatan wisata seperti menghubungkan antar desa Kawasan wisata yang terdapat di Kecamatan Purwosari: Klampok, Parangendog, Watugupit, Purwosari. Meski demikian, pemerintah juga perlu menyadari bahwa banyak masyarakat yang kini telah kembali bekerja sebagai peternak karena pekerjaan sebagai peternak dianggap lebih menjanjikan. Apabila sebagian besar masyarakat memilih untuk bekerja sebagai peternak, maka 
sebaiknya masyarakat tetap tidak diperbolehkan untuk kembali membangun di lahan rumahnya yang termasuk dalam Kawasan Rawan Bencana karena hal ini akan sangat membahayakan.

\section{PENUTUP \\ Simpulan}

Bencana gempa bumi membuat peternak yang tinggal di wilayah studi kehilangan pekerjaannya. Hal yang membuat peternak kehilangan pekerjaan antara lain kematian ternak, uang ganti rugi tidak digunakan untuk membeli ternak, kondisi tempat penampungan tidak mendukung, serta kesulitan mencari pakan ternak. Meski demikian, ternyata kerusakan wilayah akibat bencana menjadi daya tarik wisata sehingga dibuka lah Kawasan Wisata Gunung Kidul. Selain karena adanya daya tarik wisata, hal lain yang menjadi alasan dibukanya Kawasan Wisata Gunung Kidul adalah kemauan masyarakat untuk berusaha bersama memulihkan kondisi ekonomi yang terpuruk akibat bencana. Pembukaan Kawasan Wisata Gunung Kidul ini terbukti mampu memberikan peluang kerja bagi masyarakat. Dengan demikian, alasan perubahan pekerjaan masyarakat di wilayah studi adalah hilangnya pekerjaan masyarakat sebagai peternak dan terbukanya peluang kerja di kawasan wisata Gunung Kidul. Ada pun jenis-jenis pekerjaan yang ada di kawasan wisata tersebut antara lain penjual makanan di warung, penjual suvenir, penyedia jasa angkut ojek dan kendaraan lainnya serta petugas tiket dan parkir. Meski mampu membantu masyarakat untuk pulih dari bencana, namun daya tarik Kawasan Wisata Gunung Kidul menunjukkan kecenderungan menurun, terlihat dari jumlah pengunjung dan hasil penjualan tiket yang semakin berkurang serta pemandangan kerusakan yang semakin hilang. Dengan demikian dikhawatirkan bahwa kegiatan di kawasan ini tidak akan berlanjut. Sampai saat ini belum ada dukungan optimal dari pemerintah untuk mengembangkan kegiatan wisata. Padahal kawasan wisata Gunung Kidul yang dikembangkan dapat menjadi suatu penghidupan yang berkelanjutan bagi masyarakat serta menciptakan ketahanan sosial.

\section{Saran}

Saran dimaksud untuk penelitian selanjutnya.

\section{DAFTAR PUSTAKA}

Basuki, Ari. "Indonesia, Supermarket Bencana". Tempo NO. 13/ XXXV/21-27 Mei 2007.
Ilmusiana.2015. Proses Terjadinya Gempabumi. http://www.ilmusiana.com/2015/12/prosesterjadinya-gempabumi.html. (diakses 21 Januari 2017).

Kementrian Pekerjaan Umum dan Perumahan Rakyat. 2010 Peta Zonasi Gempa Indonesia. 2010. Jakarta. Kementrian PUPR.

Khan, H., \& Vasilescu, L. G. (2008). Disaster Management Cycle- A Theoretical

McCool, S. F., \& Haynes, C. D. (2002). Sustainable Tourism on a Protected Area. Best Practice Protected Area Vol.8.

Peraturan Pemerintah No 21 tahun 2008 tentang Penyelenggaraan Penanggulangan Bencana. Rencana Nasional Penanggulangan Bencana. Prasetya, Tiar, S.si, et.al.. 2006. Gempa Bumi (Ciri dan Cara Menanggulanginya). Yogyakarta: Penerbit Gitanagari. Winardi, A., et.al.. 2006. Gempa (Jogja, Indonesia \& Dunia). Jakarta: PT Gramedia.

Sengara, I.W., dan Pribadi K.S, 2009, Kajian Risiko Untuk Pencegahan dan Mitigasi Bencana Gempa di Indonesia.Mengelola risiko bencana di Negara Maritim Indonesia;Upaya Mengurangi Risiko Bencana. Institut Teknologi Bandung, Bandung.

Sukandarrumidi. (2010). Bencana Alam dan Bencana Anthropogene. Jakarta: Penerbit Kanisius.

Tim Pusat Studi Gempa Nasional. 2017. Peta Sumber dan Bahaya Gempa Indonesia Tahun 2017. Jakarta : Kementrian Pekerjaan Umum dan Perumahan Rakyat.

Twigg, John. 2007. Karakteristik Masyarakat yang Tahan Bencana. Disaster risk Reduction Interagency Coordination Group. Undang-Undang No 24 tahun 2007 tentang Penanggulangan Bencana.

Winardi, A., et.al.. 2006. Gempa (Jogja, Indonesia \& Dunia). Jakarta: PT Gramedia. 